Robert Marczak

ORCID: 0000-0003-3819-1511

Szkoła Główna Handlowa w Warszawie

https://doi.org/10.19195/1733-5779.33.20

\title{
Młodzi Polacy wobec ryzyka starości
}

JEL Classification: A2, G22, G28, G41

Słowa kluczowe: ryzyko starości, świadomość ryzyka, ubezpieczenia społeczne, solidarność, zabezpieczenie dochodów na starość

Keywords: old age risk, risk awareness, social insurance, solidarity, income protection for old age

Abstrakt: Według badania ilościowego Instytutu Spraw Publicznych oraz Millward Brown z 2016 roku, zatytułowanego „Wiedza i postawy wobec ubezpieczeń społecznych”, młody wiek jest istotną cechą towarzyszącą niskiemu poziomowi wiedzy o ubezpieczeniach społecznych. W artykule poddano analizie odpowiedzi biorących w niniejszym badaniu osób w wieku 15-24 lata, w których odwołują się do postaw wobec ryzyka starości. Opracowanie wieńczą rozważania na temat potrzeby przeprowadzenia interdyscyplinarnych badań na temat skutecznego podnoszenia poziomu świadomości ryzyka ubezpieczeniowego wśród młodej części polskiego społeczeństwa.

\section{Young Poles and the risk of old age}

Abstract: According to the quantitative study of the Institute of Public Affairs and Millward Brown in 2016 titled "Knowledge and attitudes towards social insurance", young age is an important feature accompanying the low level of knowledge about social insurance. The article analyzes the answers of people participating in this study aged 15-24 who refer to attitudes towards the risk of old age. The article concludes with reflections on the need for interdisciplinary research in the area of effectively raising the level of insurance risk awareness among the young part of Polish society.

\section{Wprowadzenie}

Raport z badania Instytutu Spraw Publicznych (ISP) i Millward Brown (MB) z 2016 roku pod tytułem „Wiedza i postawy wobec ubezpieczeń społecznych” pokazuje, że ponad 90\% respondentów (próba wynosiła 1030 osób) ma małą wiedzę w zakresie ubezpieczeń społecznych, a $46 \%$ badanej populacji nie wskazuje żad- 
nego konkretnego źródła swoich informacji. Znajomość funkcjonowania systemu emerytalnego, zasad opłacania składek na ubezpieczenie emerytalne i dodatkowych instrumentów zabezpieczenia na starość również jest niska ${ }^{1}$.

Wiedza oraz niewiedza nie jest determinowana przez żadne szczególne cechy, takie jak płeć, wykształcenie, poczucie zamożności, uwarunkowania ekonomiczno-społeczne, a także postawy (zaufanie do ZUS, opinia o składkach na ubezpieczenia społeczne, oszczędzanie na starość, opinie o odpowiedzialności za zabezpieczenie dochodów na starość).

Brak wiedzy lub niski jej poziom dotyczy przeważnie osób młodych (66\% w wieku 15-19 lat), uczących się (69\%). Wyraźna jest też grupa świadczeniobiorców pobierających emeryturę (46\%) lub rentę (59\%). Obie grupy łączy przeważnie nieaktywność zawodowa, choć znajdują się po jej dwóch stronach. Ci drudzy, będący w roli beneficjentów, mogą czuć się zwolnieni z obowiązku pozyskiwania nowej wiedzy, a także nie odczuwać takiej potrzeby, jako że już pobierają dożywotnio świadczenie, a zatem ryzyko utraty źródła dochodu ich nie dotyczy.

W badaniach z 2016 roku pojawiło się również pytanie o źródła, z których respondenci najchętniej uzyskiwaliby wiedzę o ubezpieczeniach społecznych: $20 \%$ osób odpowiada, że skorzystałoby z kontaktu z pracownikami ZUS, a 15\% odwiedziłoby stronę internetową tej instytucji. Dla $16 \%$ populacji z badania takim źródłem informacji jest telewizja. Wyniki dla pozostałych odpowiedzi oscylują wokół najwyżej kilku procent. Pojawia się też najliczniejsza grupa konsekwentnie niezainteresowana pozyskiwaniem wiedzy o ubezpieczeniach społecznych (44\%). Konsekwencję uzasadnia przede wszystkim to, że w tej grupie zawiera się większość osób, które w podobnym tonie odpowiadają na pytanie o źródło tej wiedzy u respondentów, jak i źródło wiedzy uznane przez nich za wiarygodne w tym obszarze. W kontekście rozważań na temat skuteczności popularyzowania wiedzy o ubezpieczeniach społecznych przez ZUS (lub inne wymienione wcześniej podmioty) i wzrostu świadomości ryzyka słuszny wydaje się postulat, aby najpierw zastanowić się nad tym, dlaczego tak liczna grupa badanych nie jest zainteresowana poszerzaniem swojej wiedzy, a dopiero ewentualnie później dlaczego znajomość tej problematyki jest tak niska. Być może jest też tak, że część obywateli dąży do uzyskania tej wiedzy, ale pewne okoliczności ich od tego odwodzą, na przykład nieczytelne lub trudno dostępne informacje, ciągle zmieniające się ustawodawstwo, stopień skomplikowania materii ubezpieczeniowej. Wypada się jednak zgodzić ze stwierdzeniem, że sytuacja, w której obywatele dążą do pozyskiwania wiedzy o ubezpieczeniach społecznych, jest pożądana. Warto się zatem

${ }^{1}$ Więcej na ten temat zob. m.in. R. Marczak, Wiedza Polaków o systemie emerytalnym: wyniki badań empirycznych, „Polityka Społeczna” 2016, nr 1; D. Owczarek, Niski poziom wiedzy a wyrazista postawa Polaków wobec ubezpieczeń społecznych i Zakładu Ubezpieczeń Społecznych, „Ubezpieczenia Społeczne. Teoria i praktyka” 2017, nr 1; Raport z badań ,Wiedza i postawy wobec ubezpieczeń społecznych”, Instytut Spraw Publicznych, Warszawa 2016. 
przyjrzeć wynikom badania ISP i MB z 2016 roku pod kątem cech pojawiających się u respondentów konsekwentnie niezainteresowanych.

Grupa respondentów określona w badaniu jako ,ignoranci” nie tylko niewiele wie $(71 \%$ to osoby z najniższym poziomem wiedzy, czyli takie, które udzieliły mniej niż 10\% poprawnych odpowiedzi), ale także nie ma poglądów na temat systemu ubezpieczeń społecznych. W większości pytań jest to około 70\% odpowiedzi: „Nie wiem/Trudno powiedzieć”. Ta grupa nie ma zdania na temat tego, czy należy płacić podatki, składki na ubezpieczenia społeczne, czy państwo powinno być odpowiedzialne za zabezpieczenie dochodów na starość, czy ZUS jest dla nich instytucją zaufania publicznego i jaka jest ich opinia o jego działalności. Ignorancja i brak zainteresowania ubezpieczeniami społecznymi odnosi się przede wszystkim do osób młodych.

Celem niniejszego artykułu jest wskazanie na podstawie wyników badania ISP i MB cech młodych respondentów, które odwołują się do ich postaw wobec ubezpieczeń społecznych, w tym wobec kwestii odpowiedzialności za zabezpieczenie dochodów na starość. Idea ubezpieczeń społecznych w Polsce, których częścią jest zabezpieczenie emerytalne, opiera się na zasadzie solidarności — zarówno międzypokoleniowej, jak i wewnątrzgeneracyjnej ${ }^{2}$. Przymus i powszechność ubezpieczeń społecznych powodują, że niezależnie od postaw obywateli większość osób aktywnych ekonomicznie współtworzy wspólnotę składkujących na aktualnie wypłacane świadczenia ${ }^{3}$. Ubezpieczenia społeczne zaś realizowane są przez wyznaczone do tego instytucje ${ }^{4}$. Opracowanie zwieńczą wnioski dotyczące skutecznego podniesienia poziomu świadomości w zakresie ryzyka starości u osób młodych.

\section{Młodzi Polacy o polskim systemie ubezpieczeń społecznych, systemie emerytalnym i stosunku do solidarności międzypokoleniowej}

Badanie ISP i MB zostało przeprowadzone z wykorzystaniem metod ilościowych i jakościowych, a realizowane równolegle na przełomie lipca i sierpnia 2016 roku z zastosowaniem narzędzi badawczych podzielonych na takie same bloki tematyczne: dotyczących wiedzy o ubezpieczeniach społecznych w polskim społeczeństwie, źródeł jej pozyskiwania oraz postaw wobec ubezpieczeń społecznych. W wypadku badania jakościowego zrealizowanego przy wykorzystaniu techniki zogniskowanego wywiadu grupowego (ang. focus group interview, FGI) uwzględniono transkrypcję wywiadu przeprowadzonego na jednorodnej grupie osób uczących się (pełnoletnich uczniów oraz studentów) — ankiety zrealizowa-

${ }^{2}$ K. Antonów, The scope of risk community solidarity, „Ubezpieczenia Społeczne. Teoria i praktyka" 2019, $\mathrm{nr} 2$.

${ }^{3}$ H. Pławucka, [w:] Encyklopedia prawa, red. U. Kalina-Prasznic, Warszawa 2004, s. 951-952.

${ }^{4}$ W. Szubert, Ubezpieczenia społeczne. Zarys systemu, Warszawa 1987, s. 9, 47, 66. 
no w Warszawie. W ramach wyników badania ilościowego na potrzeby artykułu analizie poddano grupę osób $\mathrm{w}$ wieku $15-24$ lata $(\mathrm{n}=144)$ wydzieloną $\mathrm{z}$ reprezentatywnej próby polskiego społeczeństwa $(\mathrm{n}=1030)$.

\section{Analiza wypowiedzi w grupie FGI}

Wypowiedzi uczniów i studentów wskazują na indywidualistyczne podejście do ochrony ryzyka starości. Osoby te mają bardzo ograniczone zaufanie do państwa oraz do Zakładu Ubezpieczeń Społecznych (ZUS). Nie wierzą, że otrzymają świadczenie (lub świadczenie o wysokości adekwatnej do wartości wniesionych składek), kiedy dożyją starości, o ile do niej dożyją („A mi to się wydaje, że my i tak nie dożyjemy do późna, bo spójrzmy na to, co się dzieje, jaka jest żywność, jak jemy...”). Badani uważają, że aktualnie obowiązek zabezpieczenia dochodów na starość ponosi państwo, gwarantując powszechną minimalną ochronę socjalną, ale ze względu na słabą kondycję państwa i systemu emerytalnego lepiej tę odpowiedzialność ponosić osobiście, mając pełną kontrolę nad grodzonymi środkami (,Jakiś wgląd w to, co się dzieje z moimi pieniędzmi, jak one się obracają i na co są przeznaczane"). Pojawia się jednak wypowiedź, która świadczy o tym, że indywidualistyczne podejście, to jest samodzielne oszczędzanie i rezygnacja z państwowej organizacji systemu emerytalnego, może również skutkować niewystarczającym poziomem środków finansowych w wypadku realizacji ryzyka starości:

No dobra, ale jest też coś takiego, że pieniądz traci na wartości i my nie wiemy tego, czy sobie odłożymy teraz tam te pieniądze, załóżmy teraz mają taką, a nie inną wartość, my sobie odłożymy te pieniądze, ale my je trzymamy i załóżmy, jeżeli nie zainwestujemy w jakieś posiadłości czy coś, no to te pieniądze tak naprawdę nic nie znaczą, bo pieniądz się od tak może zmienić, po prostu w każdej chwili wartość może zmienić i to nie jest żadne zabezpieczenie, jakby ludzie tak myśleli, takim tokiem i sami sobie chcieli zapewnić przyszłość, w sensie jakąś emeryturę czy coś, to naprawdę ciężko by było im i po prostu mogliby rzeczywiście marnie spędzić te swoje jakieś ostatnie lata starości.

[...] dostajesz te $800 \mathrm{zł}$, a nie masz pewności, jak będziesz sobie sama odkładała, że np. pieniądz tak nie straci na wartości, że to, co ty sobie odłożysz za te parędziesiąt lat, tak naprawdę nie starczy ci na przeżycie rok.

O nieskuteczności aktualnej konstrukcji systemu emerytalnego ze względu na jego repartycyjny charakter świadczy następujące zdanie jednej z respondentek:

Gdzieś usłyszałam jakąś opinię taką, że nasze pokolenie, w sensie aktualnych studentów, nie ma co liczyć na emeryturę, bo starzejące się społeczeństwo i tak naprawdę te składki, które są w tym momencie wpłacane, właśnie na te całe ubezpieczenia emerytalne, czy tam inne, które powinny być w teorii inwestowane, żeby jakoś tam zaprocentowały, żebyśmy później te emerytury mieli, to tak naprawdę idą na zaspokojenie potrzeb tych aktualnych, czyli tego starzejącego się społeczeństwa i tego, że mamy w tym momencie więcej ludzi pobierających te emerytury niż 
ludzi, którzy te składki de facto składają. I wydaje mi się, że może dojść do jakiejś takiej chorej sytuacji, że jak my będziemy tych składek potrzebowali, czyli jak osiągniemy ten wiek emerytalny, który pewnie dojdzie do 90 lat, jak dalej to wszystko tak będzie wyglądało, że po prostu no nie będzie już nawet z czego łatać tej dziury budżetowej, nie będzie już skąd pożyczać, bo w tym momencie, gdzie próbując ze służby zdrowia ściągać, w sensie z resortu zdrowia właśnie, ściągać pieniądze na składki emerytalne, no to już troszeczkę się robi nam nie za ciekawa sytuacja.

Ustawowe gwarancje wypłacalności systemu również są podawane w wątpliwość, o czym świadczy przywoływanie przykładu kryzysu gospodarczego w Grecji czy braku zaufania do aktualnie rządzącej w Polsce formacji politycznej. Badani nie wierzą także w trwałość systemu odnośnie do reform często rotujących partii rządzących.

Samo istnienie systemu ubezpieczeń społecznych ma na celu stworzenie złudnego poczucia bezpieczeństwa (,żeby obywatele mieli zaufanie”, „uspokoić nastroje społeczeństwa”, ,aspekt psychologiczny”), ale dla obecnego młodego pokolenia nie zagwarantuje wypłaty emerytur w adekwatnej wysokości (,Ja też przygotowuję się na to, że nie dostanę tej emerytury, patrząc po tym, jak ludzie starsi teraz dostają te grosze, to już nasze pokolenie to chyba nawet nie ma szans, żeby dostało chociaż 50 zł”) w stosunku do wniesionego wkładu pracy (,że się pracuje, załóżmy, te 30 lat, po czym na emeryturze jest się — tak przeciętnie człowiek chyba żyje tak do 70-75 lat — no to pobieramy te 10-15 lat emerytury, więc to jest trochę mało adekwatne do tego, co przez całe życie przepracowaliśmy").

Młodzi respondenci niechętnie odnoszą się do istoty solidaryzmu społecznego ${ }^{5}$, uważając za niesprawiedliwe płacenie składek na ubezpieczenie emerytalne na osoby, które z własnej woli są nieaktywne ekonomicznie i nie wnoszą swojego wkładu w finanse systemu emerytalnego:

jedni pracują ciężej, więcej, nie wiem, czy z ambicji, czy bo taka jest praca, a inni albo właśnie nie pracują, albo pracują lżej, i dlaczego osoba, która więcej przepracowała, ma też dokładać się do mniejszej de facto emerytury osoby, która pracowała mniej. Dlaczego ona ma oddawać od siebie to, co zarobiła na siebie i starała się sama przez całe swoje życie, żeby mieć taką wysokość emerytury, jaką ma.

Ja też jestem za tym, żeby każdy tyle, ile przepracował, to tyle dostał. To jest wtedy sprawiedliwe wobec wszystkich. Często się zdarza, że ludziom po prostu się nie chce pracować i albo się rejestrują jako bezrobotni, co wtedy też są ubezpieczeni, albo ciężko pracują i to jest bardzo uczciwe.

Tyle przepracowałem, czy tam bym przepracował, i tyle samo bym chciał dostać.

I tak najgorzej mają ci, co mają własną działalność, bo dostają najmniejsze emerytury pomimo tego, że załóżmy, wypracowali dużo, ciężko, starali się i tak dalej, a i tak mają tę minimalną.

5 O solidaryzmie w ubezpieczeniach społecznych zob. T. Szumlicz, Ubezpieczenie w polityce społecznej. Teksty i komentarze, Warszawa 2015, s. 325-330. 
Młodzi respondenci pomimo słabej oceny systemu emerytalnego w ogóle nie wypowiadają się na temat Otwartych Funduszy Emerytalnych i dodatkowych form zabezpieczenia dochodów na starość. Niewiele również wiedzą na temat instrumentów III filaru ${ }^{6}$.

$\mathrm{W}$ trakcie wywiadu grupowego omówiono także kwestię wiedzy polskiego społeczeństwa w zakresie ubezpieczeń społecznych. Zdaniem respondentów nie ma odpowiednio przygotowanej edukacji na ten temat, a przepisy regulujące funkcjonowanie systemu są dla większości społeczeństwa zbyt skomplikowane, co skutkuje jego biernością i „niedbaniem o swój interes”. Dodatkowo obraz systemu ubezpieczeń społecznych zniekształcają media. Respondenci uważają, że większość obywateli jest w sferze budowania świadomości ubezpieczeniowej pozostawiona sama sobie, a ewentualne działania edukacyjne państwa byłyby zbyt czasochłonne, aby osiągnąć pożądany rezultat („To jest długi czas przekonywania się, jak to działa, patrzenie, jak to faktycznie wygląda") lub mogą się okazać spóźnione („Później państwo będzie chciało dotrzeć do tego człowieka, to już nie dotrze, bo tak ma być i koniec").

\section{Postawy wobec ryzyka starości według wyników badania ilościowego}

Młodzi respondenci gorzej oceniają działalność ZUS (wykres 1), lecz także mają do niego nieco mniejsze zaufanie (wykres 2) niż cała badana populacja. Wyraźnie widać, że wśród młodych ludzi jest również więcej osób, które w tych kwestiach nie mają wyrobionej opinii (w stosunku do całej populacji o 20,4\% więcej w wypadku oceny funkcjonowania zaufania i o $14,1 \%$ więcej w odniesieniu do zaufania do tej instytucji). Prawie co trzecia osoba w wieku 15-24 lata nie potrafi wskazać, co sądzi o działalności ZUS, co czwarta z tej grupy (15-24 lata) ma negatywne zdanie (,zdecydowanie źle” oraz „,raczej źle”) oraz prawie co trzecia nie ma opinii, czy jest to instytucja godna zaufania. Tylko $13,9 \%$ młodych badanych ocenia jej działalność dobrze, choć bez zdecydowania, ale ograniczone zaufanie ma już co trzecia osoba $\mathrm{z}$ analizowanej grupy.

${ }^{6} \mathrm{O}$ wiedzy polskiego społeczeństwa na temat instrumentów dobrowolnego zabezpieczenia na starość zob. T. Jarocki, Postawy Polaków wobec oszczędzania w II i III filarze w świetle znajomości zasad systemu emerytalnego, „Ubezpieczenia Społeczne. Teoria i praktyka” 2017, nr 4. 


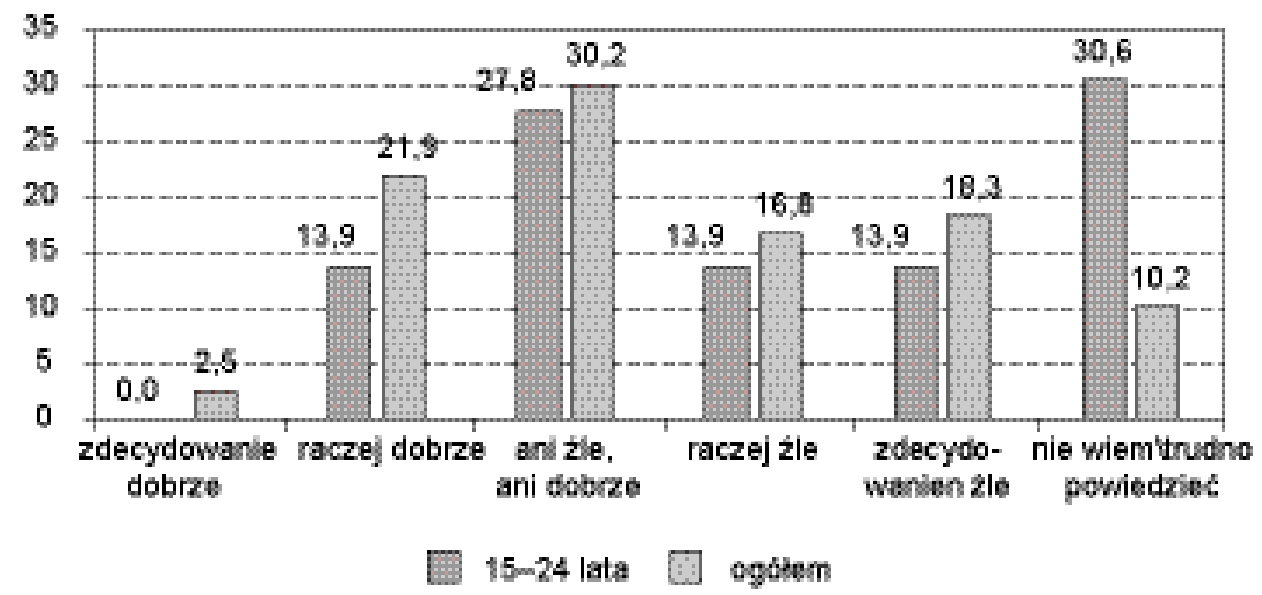

Wykres 1. Ocena funkcjonowania ZUS: osoby w wieku 15-24 lata $v s$ respondenci ogółem (w \%)

Źródło: opracowanie własne na podstawie badania Instytutu Spraw Publicznych i Millward Brown, „Wiedza i postawy wobec ubezpieczeń społecznych", 2016.

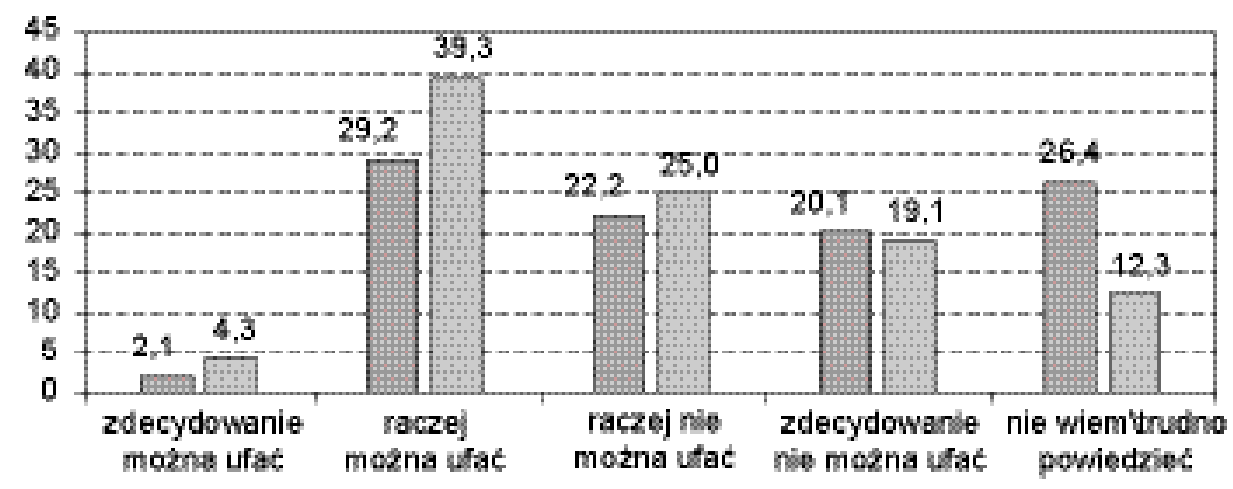

\section{5-24 lata ogolem}

Wykres 2. Zaufanie do ZUS: osoby w wieku 15-24 lata vs respondenci ogółem (w \%)

Źródło: opracowanie własne na podstawie badania Instytutu Spraw Publicznych i Millward Brown, op. cit. 
Tabela 1. Opinia na temat solidarności ubezpieczeniowej oraz społecznej: osoby w wieku 15-24 lata vs respondenci ogółem (w \%)

\begin{tabular}{|c|c|c|c|c|c|c|c|c|c|c|}
\hline \multirow[t]{2}{*}{ Kategoria opinii } & \multicolumn{2}{|c|}{ 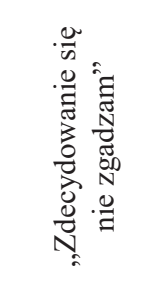 } & \multicolumn{2}{|c|}{ 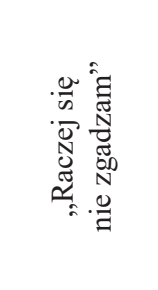 } & \multicolumn{2}{|c|}{ 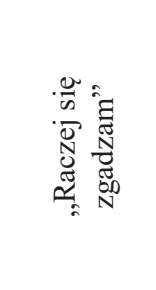 } & \multicolumn{2}{|c|}{ 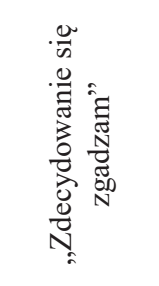 } & \multicolumn{2}{|c|}{ 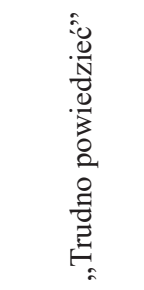 } \\
\hline & 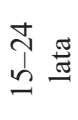 & $\frac{1}{0}$ & 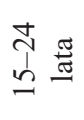 & $\frac{1}{0}$ & 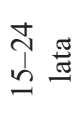 & $\frac{1}{0}$ & 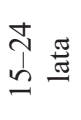 & $\frac{\tilde{0}}{0.0}$ & 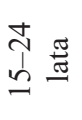 & $\frac{\Xi}{0}$ \\
\hline $\begin{array}{l}\text { Ludzie przede wszyst- } \\
\text { kim starają się służyć } \\
\text { pomocą innym }\end{array}$ & 7,6 & 6,6 & 27,8 & 25,9 & 41,7 & 44,4 & 13,2 & 13,7 & 9,7 & 9,4 \\
\hline $\begin{array}{l}\text { Dzieci powinny } \\
\text { pomagać finansowo } \\
\text { rodzicom } \\
\text { w podeszłym wieku }\end{array}$ & 5,6 & 4,7 & 11,1 & 13,8 & 47,9 & 48,4 & 22,9 & 23,5 & 12,5 & 9,6 \\
\hline $\begin{array}{l}\text { Niektórzy ludzie są } \\
\text { więcej warci od innych }\end{array}$ & 20,1 & 11,4 & 22,2 & 20,2 & 36,8 & 42,5 & 9,7 & 16,8 & 11,1 & 9,1 \\
\hline $\begin{array}{l}\text { Powinniśmy za wszelką } \\
\text { cenę starać się traktować } \\
\text { innych ludzi w taki sam } \\
\text { sposób }\end{array}$ & 4,9 & 2,3 & 9,7 & 9,9 & 47,9 & 51,3 & 27,8 & 29,7 & 9,7 & 6,8 \\
\hline $\begin{array}{l}\text { Niektóre grupy ludzi nie } \\
\text { zasługują na szacunek }\end{array}$ & 18,8 & 12,8 & 18,8 & 21,4 & 36,1 & 39,7 & 13,9 & 16,6 & 12,5 & 9,5 \\
\hline $\begin{array}{l}\text { Powinniśmy dążyć do } \\
\text { tego, aby dochody } \\
\text { wszystkich ludzi były } \\
\text { w miarę wyrównane }\end{array}$ & 3,5 & 3,6 & 19,4 & 15,3 & 42,4 & 45,1 & 26,4 & 30,2 & 8,3 & 5,7 \\
\hline $\begin{array}{l}\text { Każdy z nas jest } \\
\text { kowalem swojego losu }\end{array}$ & 0,0 & 1,9 & 9,0 & 10,9 & 47,9 & 47,7 & 38,9 & 33,6 & 4,2 & 5,9 \\
\hline $\begin{array}{l}\text { Ludzie tacy jak ja, } \\
\text { działając wspólnie } \\
\text { z innymi, mogą pomóc } \\
\text { potrzebującym lub } \\
\text { rozwiązać niektóre } \\
\text { problemy swojego } \\
\text { środowiska, osiedla, wsi } \\
\text { lub miasta }\end{array}$ & 2,8 & 3,3 & 8,3 & 12,6 & 56,9 & 54,5 & 22,2 & 20,7 & 9,7 & 8,9 \\
\hline
\end{tabular}




\begin{tabular}{|l|l|l|l|l|l|l|l|l|l|l|}
\hline $\left.\begin{array}{l}\text { Powinniśmy wspierać } \\
\text { z naszych podatków } \\
\text { grupy } \\
\text { nieuprzywilejowane } \\
\begin{array}{l}\text { w społeczeństwie, } \\
\text { np. bezrobotnych, } \\
\text { biednych, niepełno- } \\
\text { sprawnych, } \\
\text { bezdomnych }\end{array}\end{array}\right)$ & 6,9 & 6,2 & 18,1 & 17,2 & 43,8 & 48,8 & 16,7 & 17,0 & 14,6 & 10,8 \\
\hline $\begin{array}{l}\text { Nierówności społeczne } \\
\text { powinny być wyelimino- } \\
\text { wane }\end{array}$ & 2,8 & 3,9 & 14,6 & 11,4 & 45,8 & 48,9 & 29,9 & 28,7 & 6,9 & 7,1 \\
\hline $\begin{array}{l}\text { Bezrobotni i biedni sami } \\
\text { odpowiadają za swoją } \\
\text { niekorzystną sytuację }\end{array}$ & 11,8 & 10,3 & 22,2 & 31,0 & 43,1 & 34,0 & 12,5 & 13,7 & 10,4 & 11,1 \\
\hline $\begin{array}{l}\text { Zabezpieczenie osób } \\
\text { starszych jest kwestią } \\
\text { ogólnospołeczną } \\
\text { i wszyscy powinniśmy } \\
\text { o to zabiegać }\end{array}$ & 0,0 & 2,0 & 13,9 & 9,9 & 40,3 & 47,8 & 34,0 & 34,4 & 11,8 & 5,9 \\
\hline $\begin{array}{l}\text { Zabezpieczenie na } \\
\text { starość powinno zależeć } \\
\text { wyłącznie od indywidu- } \\
\text { alnej przezorności }\end{array}$ & 6,3 & 8,0 & 24,3 & 23,9 & 40,3 & 41,8 & 16,7 & 16,6 & 12,5 & 9,7 \\
\hline
\end{tabular}

Źródło: opracowanie własne na podstawie badania Instytutu Spraw Publicznych i Millward Brown, op. cit.

Na wiele pytań dotyczących solidarności społecznej (w tym solidarności w obszarze ubezpieczeń społecznych) młodzi respondenci oraz cała badana populacja odpowiadali podobnie.

Stosunek odpowiedzi negatywnych (,zdecydowanie się nie zgadzam” oraz „raczej się nie zgadzam”) do pozytywnych („,zdecydowanie się zgadzam” i „, ,aczej się zgadzam") wskazuje, że:

— więcej osób wierzy w chęć społeczeństwa do niesienia pomocy potrzebującym $(35,4 \%$ / 54\%);

— większość zgadza się ze stwierdzeniem, że należy pomagać finansowo rodzicom w podeszłym wieku (16,7\% / 70,8\%);

- ankietowani są podzieleni w kwestii, czy jedne osoby są warte więcej od innych $(42,3 \%$ / 46,5\%), a połowa badanych uważa, że niektórzy nie zasługują na szacunek (27,6\% / 50\%), choć większość jest zdania, że należy traktować innych w taki sam sposób bez względu na wszystko $(14,6 \%$ / 75,7\%), a wszelkie nierówności społeczne powinny zostać wyeliminowane (17,4\% / 75,7\%);

— za równością dochodów opowiadają się dwie trzecie respondentów $(22,9 \%$ / 68,8\%); 
— przeważająca większość jest zdania, że los każdego leży w jego własnych rękach $(9,01 \%$ / 81,3\%), a ponad drugi badany stwierdza, że za złą sytuację osób biednych i bezrobotnych odpowiadają oni sami (34\% / 55\%); podobny jest stosunek tych, którzy uważają, że zabezpieczenie środków na starość zależy od indywidualnej przezorności $(34 \%$ / 55,6\%) — co ciekawe, również połowa młodszych badanych w innym pytaniu jako stronę najbardziej odpowiedzialną w tym obszarze wskazuje państwo (wykres 3);

— większość respondentów sądzi, że są w stanie z pomocą innych wesprzeć potrzebujących $(11,1 \%$ / 79,1\%), a nieco mniej niż dwie trzecie młodych badanych uznaje, że można to zrobić przez płacenie podatków $(25 \%$ / 60,5\%).

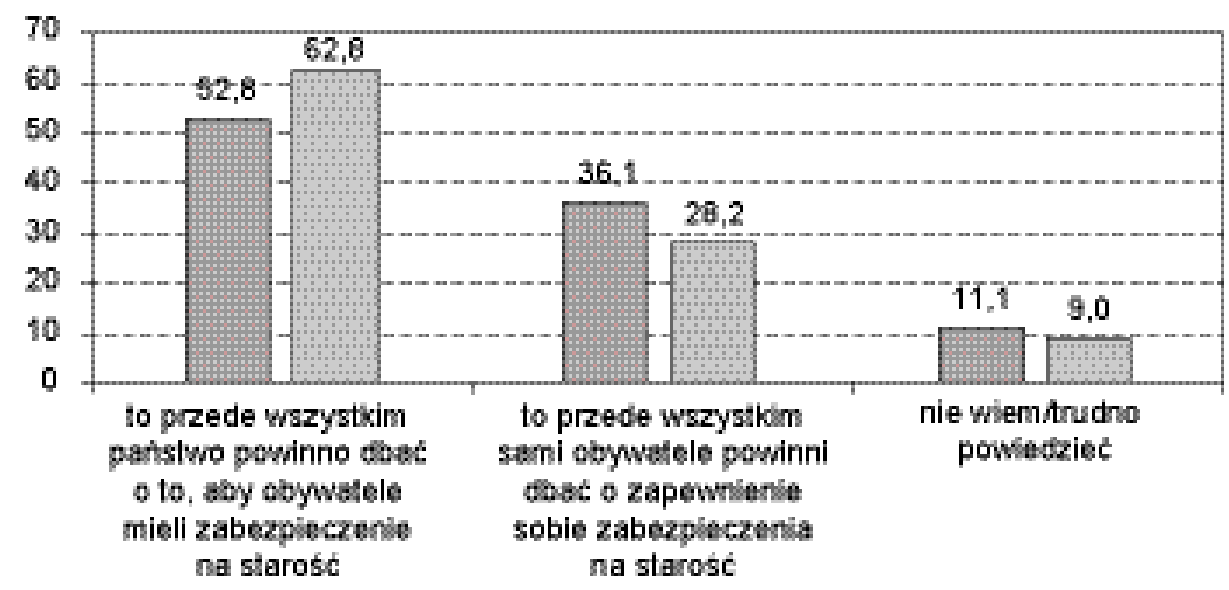

\section{24 lata ogótem}

Wykres 3. Opinia na temat odpowiedzialności za zabezpieczenie na starość: osoby w wieku 15-24 lata $v s$ respondenci ogółem (w \%)

Źródło: opracowanie własne na podstawie badania Instytutu Spraw Publicznych i Millward Brown, op. cit.

Młodzi nieco bardziej od całej populacji badanych sprzeciwiają się twierdzeniu, że niektórzy ludzie są warci więcej od innych. Indywidualistyczne, ale niezbyt zdecydowane podejście jest również widoczne, kiedy respondenci wyrażają swoją opinię o tym, czy bezrobotni i biedni osobiście odpowiadają za swoją niekorzystną sytuację. Przy odpowiedzi na te pytania w całej próbie było również najmniej niezdecydowanych. 


\section{Jak skutecznie podnosić świadomość ryzyka starości w ubezpieczeniach społecznych u osób młodych?}

Stosunek młodej części społeczeństwa do ryzyka starości należy potraktować jako element dyskusji na temat świadomości ubezpieczeniowej. Rozważania w szerszym kontekście toczą się już od wielu lat i ich ślady można znaleźć w licznych publikacjach ${ }^{7}$. Bardzo dużo autorów podnosi, że świadomość ubezpieczeniowa (niekiedy nazywaną też świadomością ryzyka) wskazuje na stan intelektualny jednostek oraz takie atrybuty, jak wiedza, umiejętności, postawy. Przegląd dostępnej literatury ${ }^{8}$ pokazuje, że świadomość ubezpieczeniową rozumie się poprzez uświadomienie sobie przez jednostkę określonych ryzyk, skutków ich realizacji, wiedzę o możliwościach zabezpieczenia się przed nimi, a w konsekwencji odpowiednie działania o charakterze przezornościowym. Takie ujęcie odwołuje się do przeważającego w środowisku naukowym w kwestii ryzyka podejścia sekwencyjnego, w którym kluczowe jest słowo „realizacja”, a zagrożenie dzieli się na trzy fazy: niebezpieczeństwo potencjalne, akt (realizacja niebezpieczeństwa) oraz efekt (skutki niebezpieczeństwa) ${ }^{9}$.

Trudno jednak znaleźć rozważania wyodrębniające świadomość ryzyka w ubezpieczeniach społecznych. Jak zatem należy ją rozumieć i w jaki sposób ją zmierzyć?

Świadomość ubezpieczeniową w kontekście ubezpieczenia komercyjnego można mierzyć przez badanie wiedzy o potencjalnych ryzykach i dostępnych na rynku produktach ubezpieczeniowych, a w warunkach naturalnych przez udział obywateli w korzystaniu z tych ubezpieczeń. W wypadku świadomości ryzyka w ubezpieczeniach społecznych trudność powoduje ich powszechny przymus wynikający ze stosowania przepisów o ubezpieczeniach społecznych, a tym samym niemożliwość wyboru w kwestii legalnego zrezygnowania z ubezpieczeń społecznych. Udział obywateli w tych ubezpieczeniach jest powszechny i obowiązkowy, a warunkiem podlegania tym ubezpieczeniom jest prowadzenie zarejestrowanej działalności gospodarczej lub legalne zatrudnienie oraz płacenie składek na ubezpieczenia społeczne z tych tytułów.

Świadomość w tym zakresie może być badana przede wszystkim na poziomie deklaratywnym poprzez znajomość przepisów prawnych w zakresie ubezpieczeń społecznych, zadań państwowych instytucji ubezpieczeniowych (ZUS, KRUS),

7 Część z nich wymienia m.in. W. Sułkowska, Świadomość społeczna w obszarze ubezpieczeń społecznych w'sietle badań naukowych, [w:] Upowszechnianie wiedzy i edukacji w zakresie ubezpieczeń społecznych, Kraków 2013, s. 9.

8 T. Szumlicz, Ubezpieczenie w polityce społecznej, [w:] Spoleczne aspekty rozwoju rynku ubezpieczeniowego, red. T. Szumlicz, Warszawa 2010, s. 64.; zob. także W. Sułkowska, op. cit.; N.M. Pazio, A. Formanowska, Struktura świadomości ubezpieczeniowej w świetle badań, „Wiadomości Ubezpieczeniowe" 2002, nr 3, s. 4.

9 J. Monkiewicz, Podstawy ubezpieczeń, t. 1. Mechanizmy i funkcje, Warszawa 2000, s. 17. 
finansów publicznych w obszarze redystrybucji składek na ubezpieczenia społeczne i podatków.

Omówione wcześniej badanie ISP i MB wyraźnie pokazuje, jak istotna jest rola edukacji w kształtowaniu odpowiednich postaw, a także jak bardzo powszechności tej edukacji brakuje. Przekazanie wiedzy i umiejętności w zakresie ubezpieczeń na poziomie szkolnym może się odbywać poprzez włączenie treści ubezpieczeniowych do podstawy programowej, realizację projektów, organizację konkursów. Szkolna edukacja ubezpieczeniowa służy wszak przygotowaniu młodych osób do aktywnego i świadomego funkcjonowania w życiu gospodarczym - gospodarowania swoimi finansami i zarządzania ryzykiem ${ }^{10}$. W opinii M. Pogonowskiego edukacja młodzieży (na poziomie szkolnym i uniwersyteckim) ma szczególne znaczenie, gdyż w tym okresie budowana jest świadomość obywatelska, kształtuje się sposób postrzegania rzeczywistości (również jej aspektów finansowych), człowiek nabiera gotowości do podejmowania dojrzałych decyzji ${ }^{11}$. Edukacja ubezpieczeniowa na tym poziomie powinna koncentrować się przede wszystkim na:

— świadomości ryzyka — wiedzy o zagrożeniach i różnorodności ryzyka;

- metodach zarządzania ryzykiem, w tym wiedzy o istocie ubezpieczenia;

— przezorności ubezpieczeniowej związanej na przykład z wypadkiem samochodowym, uszczerbkiem na zdrowiu;

— ubezpieczeniowej wspólnocie ryzyka ${ }^{12}$.

Zgodnie z ustawą o systemie ubezpieczeń społecznych Zakład Ubezpieczeń Społecznych ${ }^{13}$ jest zobowiązany do podejmowania działań upowszechniających wiedzę z zakresu ubezpieczeń społecznych. Zdaniem B. Owsiak

Zakład Ubezpieczeń Społecznych dostrzega, że niezbędne jest podnoszenie świadomości ubezpieczeniowej, skłanianie do przezorności i zapobiegliwości przejawiających się w szukaniu dodatkowych form ubezpieczenia i wykształcaniu nawyku systematycznego planowania swojej przyszłości, wykształcaniu nawyku oszczędzania na okres po zakończeniu aktywności zawodowej, a przede wszystkim ubezpieczeniu się od różnych życiowych ryzyk ${ }^{14}$.

Zakład prowadzi wiele zabiegów o charakterze edukacyjnym i informacyjnym. Są to działania zarówno podejmowane w systemach szkolnym i uczelnianym, jak i skierowane do pozostałej części społeczeństwa. Głównym celem aktywności $\mathrm{w}$ tym zakresie jest zapoznanie ich adresatów z zasadami funkcjonowania systemu ubezpieczeń społecznych oraz zrozumienie jego istoty. ZUS szuka również niekonwencjonalnych, nowoczesnych sposobów przekazywania wiedzy o ubez-

10 M. Łebkowska, Edukacja ubezpieczeniowa młodzieży ponadgimnazjalnej w systemie szkolnym i poza nim, „Ubezpieczenia Społeczne. Teoria i praktyka” 2017, nr 1, s. 27.

11 B. Owsiak, Popularyzowanie wiedzy o ubezpieczeniach społecznych przez Zakład Ubezpieczeń Społecznych, „Ubezpieczenia Społeczne. Teoria i praktyka” 2017, nr 1, s. 8.

12 M. Łebkowska, op. cit., s. 26.

13 Art. 68 ust. 1 pkt 8 ustawy o systemie ubezpieczeń społecznych z dnia 13 października 1998 roku, Dz.U. Nr 137, poz. 887.

14 B. Owsiak, op. cit., s. 8. 
pieczeniach społecznych, o czym świadczą dwie zorganizowane na Uniwersytecie Pedagogicznym w Krakowie konferencje pod wspólnym tytułem „Jak uczyć o ubezpieczeniach społecznych?". W marcu 2018 roku do dyskusji na temat skutecznej edukacji zaproszono twórców gier komputerowych, aplikacji VR, słuchowisk binauralnych, ekspertów od brokeringu informacji ${ }^{15}$, a w edycji w kwietniu 2019 roku problem ten omawiano na płaszczyźnie przekazów kulturowych, które odnoszą się do ubezpieczeń społecznych ${ }^{16}$.

W kontekście cytowanych wcześniej badań Instytutu Spraw Publicznych i Millward Brown, lecz także wielu innych badań dotyczących na przykład dodatkowego oszczędzania na starość, pojawia się zasadnicze pytanie: czy działania ZUS w suboptymalnych warunkach, w których funkcjonuje (ogólnie niskie zaufanie obywateli do instytucji publicznych) realizują swoje zadanie skutecznie? Innymi słowy: czy brak działań edukacyjnych ze strony Zakładu skutkowałby takim samym, a może jednak jeszcze niższym poziomem świadomości ryzyka?

$\mathrm{Z}$ dostępnych komentarzy do ustawy o systemie ubezpieczeń społecznych trudno wywieść istotę oraz proceduralną wykładnię zapisu art. 68 o popularyzacji wiedzy o ubezpieczeniach społecznych ${ }^{17}$. Powody tego stanu rzeczy można wskazać co najmniej dwa. Po pierwsze, upowszechnianie tej wiedzy nie należy do głównych zadań ZUS — są nimi przecież ustalanie obowiązku w ubezpieczeniach społecznych, wymierzanie i pobieranie składek na ubezpieczenia społeczne, ustalanie prawa do świadczeń oraz ich wypłata. Po drugie, choć autorami komentarzy są wybitni eksperci prawa, sędziowie i dydaktycy, to jednak nie wzięli oni na siebie ciężaru eksplikacji akurat tego zagadnienia. Co więcej, nie wyjaśnił tego również ustawodawca i na próżno szukać odpowiednich wskazówek w uzasadnieniu do tego aktu prawnego.

Zarówno popularyzacja, jak i cały nurt nauki nad ubezpieczeniami społecznymi mają charakter interdyscyplinarny. Dyskurs naukowy wokół tych drugich jest prowadzony na kilku płaszczyznach:

— prawnej — bada się zakres podmiotowy i przedmiotowy wynikający z realizacji przepisów ustawy o ubezpieczeniach społecznych poprzez egzekwowanie praw oraz obowiązków uczestników systemu ubezpieczeń społecznych: ubezpieczonych, świadczeniobiorców, płatników składek (na przykład zasad ustalania obowiązku objęcia ubezpieczeniami społecznymi, zasad nabycia prawa do świadczeń z ubezpieczeń społecznych);

15 Zob. relacja z konferencji: https://www.zus.pl/o-zus/kalendarium/konferencje/konferencja-naukowa-jak-uczyc-o-ubezpieczeniach-spolecznych/o-konferencji (dostęp: 27.04.2020).

16 Zob. relacja z konferencji: https://www.zus.pl/o-zus/kalendarium/konferencje/konferencja-naukowa-swiadomosc-ryzyka-a-ryzyko-nieswiadomosci.-jak-uczyc-o-ubezpieczeniach-spolecznych-/o-konferencji (dostęp: 27.04.2020).

17 Zob. Ustawa o systemie ubezpieczeń społecznych (komentarz), red. B. Kudowska, J. Strusińska-Żukowska, Warszawa 2011; oraz Ustawa o systemie ubezpieczeń społecznych. Komentarz, red. J. Wantoch-Rekowski, Toruń-Warszawa 2007. 
— ekonomicznej — w obszarze finansowych skutków stosowania prawa o ubezpieczeniach społecznych w skali mikro- i makroekonomicznej (w tym wypadku istotny głos będą mieli również ekonometrycy, demografowie i statystycy);

— polityki społecznej — w kontekście dążenia do bezpieczeństwa socjalnego oraz społecznego, a relacje między tymi pojęciami są również przedmiotem dociekań ekonomistów i socjologów (na przykład w zakresie zarządzania ryzykiem społecznym).

Popularyzacja wiedzy zaś - jako także wielodziedzinowe zagadnienie przypuszczalnie będzie interesować co najmniej pedagoga, socjologa, antropologa, językoznawcę, medioznawcę i filozofa, o czym mogą świadczyć chociażby konkursy na upowszechnianie nauki organizowane przez Ministerstwo Nauki i Szkolnictwa Wyższego ${ }^{18}$. To powoduje, że na samym początku kłopotliwe wydaje się określenie paradygmatu badawczego do postawionego w śródty tule pytania.

$\mathrm{Z}$ powodu ograniczonych ram artykułu nie sposób tego uczynić na łamach niniejszej publikacji, ale warty zgłoszenia zdaje się postulat poszukiwań najbardziej skutecznych sposobów edukacji osób młodych interdyscyplinarną metodą naukową. Popularyzacja wiedzy o ubezpieczenia społecznych jest zadaniem nałożonym przez ustawodawcę na Zakład Ubezpieczeń Społecznych, w odpowiedzi na zadane pytanie badawcze powinno się zatem przyjąć podejście celowościowe rozumiane zgodnie $\mathrm{z}$ teorią organizacji w ramach nauk o zarządzaniu. Efektywność ekonomiczna $\mathrm{w}$ tym podejściu będzie oznaczała najpierw badanie skutecznych sposobów popularyzacji wiedzy o ubezpieczeniach społecznych, a następnie rozpoznanie nakładów (środków i zasobów) zaangażowanych do osiągnięcia tego celu ${ }^{19}$.

Do przygotowania koncepcji badania powinno się przyjąć następujące stwierdzenia:

- skuteczna popularyzacja wiedzy o ubezpieczeniach społecznych powoduje wzrost świadomości ryzyka (rozumianego jako ryzyka, od których następstw zabezpieczają ubezpieczenia społeczne);

— świadomość ryzyka przejawia się w określonym zachowaniu obywateli.

\section{Podsumowanie}

Ubezpieczenia społeczne są formą umowy międzypokoleniowej i mają wymiar etyczny. Odwołują się również do zasady solidarności wspólnoty ryzyka, rozumianej jako rozłożenie na jak najszerszą zbiorowość ciężaru ryzyka, to jest kosztu finansowania ubezpieczenia, jednak bez symetrii między wnoszonym wkładem (składką) a nabytą korzyścią (świadczeniem), do tego tylko potencjalnym, gdyż

18 Popularyzator Nauki 2016 na horyzoncie - nowe kategorie!, naukawpolsce.pap.pl (dostęp: 11.10.2018).

19 J. Zieleniewski, Organizacja i zarządzanie, Warszawa 1975, s. 232-236. 
nieprzysługującym w sytuacji, gdy ryzyko nie zostało zrealizowane, a także przy założeniu i zgodzie na nierówność w zakresie ponoszenia obciążeń składkowych zarówno w aspekcie czasu ich trwania, jak i rozmiaru ${ }^{20}$. Niezrozumienie tej koncepcji wyraźnie odzwierciedlają cytowane wcześniej wypowiedzi młodych respondentów.

\begin{tabular}{|c|ccc} 
Zależności & $\begin{array}{c}\text { Popularyzacja } \\
\text { wiedzy } \\
\text { o ubezpieczeniach } \\
\text { społecznych }\end{array}$ & $\begin{array}{c}\text { Świadomość ryzyka } \\
\text { w ubezpieczeniach } \\
\text { społecznych }\end{array}$ & $\begin{array}{c}\text { Pożądane zachowanie } \\
\text { obywateli }\end{array}$ \\
& - popularyzacja & - świadomość & obywatele \\
społeczna & (rozróżnienie na \\
Definicje & wiedzy & grupy społeczne)
\end{tabular}

Rysunek 1. Wpływ popularyzacji wiedzy o ubezpieczeniach społecznych na postawy obywateli

Źródło: opracowanie własne.

Badania nad skutecznym nauczaniem i upowszechnianiem wiedzy o ubezpieczeniach społecznych, wymiernym w podnoszeniu świadomości ryzyka, wymuszają heurystyczne ujęcie. Zdaniem K. Hagemejera istotną cechą edukacji o ubezpieczeniach społecznych, bez względu na poziom nauczania, jest jej interdyscyplinarność. Z tego względu zagadnienia z obszaru ubezpieczeń społecznych wymagają odniesienia ich między innymi do prawa, demografii, ekonomii. Warunkiem efektywnej powszechnej edukacji ubezpieczeniowej jest zatem interdyscyplinarne kształcenie ekspertów ${ }^{21}$.

Rozważania dotyczące różnych ujęć świadomości ryzyka skłaniają do przypuszczenia, że w zakresie ubezpieczeń społecznych powinna być ona przedmiotem badań następujących nauk, a ich rezultaty powinny łączyć wnioski w sposób interdyscyplinarny:

- ekonomii behawioralnej i psychologii społecznej, których przedstawiciele pokazują, że wiedza jednostki nie przekłada się na postawy. Przykładem może być zjawisko prokrastynacji, które w badaniach nad wykorzystaniem ekonomii behawioralnej w ekonomii emerytalnej objawia się tym, że choć dana osoba wie, że powinna systematycznie oszczędzać na starość, nadal tego nie robi;

— przyczyna prokrastynacji została wyjaśniona w naukach o neurobiologii. Jest ona uznawana za wynik rywalizacji dwóch ośrodków działania ludzkiego mózgu: układu limbicznego odpowiadającego za dążenie do uzyskania natychmiastowej nagrody oraz kory przedczołowej odpowiedzialnej za koncentrację, zarządzanie sobą, własną uwagą i celami oraz za postrzeganie czasu. Szerokie badania doty-

20 J. Jończyk, Prawo zabezpieczenia społecznego, Kraków 2006, s. 39-40.

21 Ibidem, s. 144-154. 
czące zjawiska prokrastynacji pokazują, że rozpatruje się ją indywidualnie (na przykład poprzez samoopisowe kwestionariusze Irrational Procrastination Scale [IPS] i Pure Procrastination Scale [PPS] ${ }^{22}$, a gdy przybiera ona charakter patologiczny, zaleca się oddziaływanie terapeutyczne. To pojęcie może być przyczynkiem do rozwinięcia rozważań na temat kampanii psychospołecznych (jako sposobu upowszechniania wiedzy o ubezpieczeniach społecznych);

— socjologii — świadomość ryzyka oraz takie pojęcia, jak bezpieczeństwo socjalne, bezpieczeństwo społeczne i ryzyka socjalne, powinny być badane przez ich społeczne postrzeganie jako element kultury (i/lub cywilizacji wewnętrznej, na przykład rozumianych w duchu Alfreda Webera) w dobie tak zwanej kultury indywidualizmu ${ }^{23}$;

- kognitywistyki, na przykład świadomość ryzyka na poziomie deklaratywnym byłaby badana wskutek doświadczenia immersyjnego jednostki (przykład: respondent uważa, że system ubezpieczeń społecznych jest niepotrzebny i nie warto ubezpieczać się od skutków niezdolności do pracy; następnie badany zakłada gogle, które przenoszą go do wirtualnej rzeczywistości, a w niej dochodzi do „wolicjonalnego zawieszenia niewiary” - termin opracowany przez Samuela Taylora Coleridge'a ${ }^{24}$ - w wykreowanym, lecz bardzo sugestywnym świecie dochodzi do wypadku i respondent staje się osobą niepełnosprawną, dzięki czemu przechodzi głęboką przemianę i to wpływa na liczne zmiany w jego „prawdziwym” życiu: jest bardziej wrażliwy na potrzeby osób z niepełnosprawnościami, prowadzi zdrowszy tryb życia, ubezpiecza się na wypadek realizacji różnych ryzyk życiowych itp.).

Wyniki takich badań mogą więc pozwolić na zidentyfikowanie sposobu, w jaki Zakład Ubezpieczeń Społecznych lub inne instytucje powinny skutecznie podnosić poziom świadomości ryzyka osób młodych.

\section{Bibliografia}

Antonów K., The scope of risk community solidarity, „Ubezpieczenia Społeczne. Teoria i praktyka” 2019 , $\mathrm{nr} 2$.

Jarocki T., Postawy Polaków wobec oszczędzania w II i III filarze w świetle znajomości zasad systemu emerytalnego, „Ubezpieczenia Społeczne. Teoria i praktyka” 2017, $\mathrm{nr} 4$.

Jończyk J., Prawo zabezpieczenia społecznego, Kraków 2006.

King M.J., The procrastination syndrome: Signs, symptoms, and treatment, „Innovative Leader” 7, 1998, nr 11.

Kłoskowska A., Socjologia kultury, Warszawa 2007, s. 72.

22 M.J. King, The procrastination syndrome: Signs, symptoms, and treatment, „Innovative Leader" 7, 1998, nr 11.

23 A. Kłoskowska, Socjologia kultury, Warszawa 2007, s. 72.

${ }^{24}$ K. Prajzner, Tekst jako świat i gra. Modele narracyjności w kulturze wspótczesnej, Łódź 2009, s. 26. 
Łebkowska M., Edukacja ubezpieczeniowa młodzieży ponadgimnazjalnej w systemie szkolnym i poza nim, „Ubezpieczenia Społeczne. Teoria i praktyka” 2017, nr 1.

Marczak R., Wiedza Polaków o systemie emerytalnym: wyniki badań empirycznych, „Polityka Społeczna" 2016, nr 1.

Monkiewicz J., Podstawy ubezpieczeń, t. 1. Mechanizmy i funkcje, Warszawa 2000.

Owczarek D., Niski poziom wiedzy a wyrazista postawa Polaków wobec ubezpieczeń spolecznych i Zaktadu Ubezpieczeń Społecznych, „Ubezpieczenia Społeczne. Teoria i praktyka” 2017, nr 1.

Owsiak B., Popularyzowanie wiedzy o ubezpieczeniach społecznych przez Zakład Ubezpieczeń Spotecznych, „Ubezpieczenia Społeczne. Teoria i praktyka” 2017, nr 1.

Pazio N.M., Formanowska A., Struktura świadomości ubezpieczeniowej w świetle badań, „Wiadomości Ubezpieczeniowe" 2002, nr 3.

Pławucka H., [w:] Encyklopedia prawa, red. U. Kalina-Prasznic, Warszawa 2004.

Prajzner K., Tekst jako świat i gra. Modele narracyjności w kulturze wspótczesnej, Łódź 2009.

Raport z badań „,Wiedza i postawy wobec ubezpieczeń społecznych”, Instytut Spraw Publicznych, Warszawa 2016.

Sułkowska W., Świadomość społeczna w obszarze ubezpieczeń społecznych $w$ świetle badań naukowych, [w:] Upowszechnianie wiedzy i edukacji w zakresie ubezpieczeń społecznych, Kraków 2013.

Szubert W., Ubezpieczenia społeczne. Zarys systemu, Warszawa 1987.

Szumlicz T., Ubezpieczenie w polityce społecznej, [w:] Społeczne aspekty rozwoju rynku ubezpieczeniowego, red. T. Szumlicz, Warszawa 2010.

Szumlicz T., Ubezpieczenie w polityce społecznej. Teksty i komentarze, Warszawa 2015.

Ustawa o systemie ubezpieczeń społecznych (komentarz), red. B. Kudowska, J. Strusińska-Żukowska, Warszawa 2011.

Ustawa o systemie ubezpieczeń spolecznych. Komentarz, red. J. Wantoch-Rekowski, Toruń-Warszawa 2007.

Zieleniewski J., Organizacja i zarządzanie, Warszawa 1975. 